\title{
THE EFFECTS OF GENDER COMPOSITION IN ACADEMIC DEPARTMENTS ON FACULTY TURNOVER
}

\author{
PAMELA S. TOLBERT, TAL SIMONS, ALICE ANDREWS, and JAEHOON RHEE*
}

\begin{abstract}
Using data collected from a sample of 50 academic departments over the years $1977-88$, the authors test several hypotheses about the effects of departmental gender composition on faculty turnover. They find that as the proportion of women in a department grew, turnover among women also increased, confirming the prediction that increases in the relative size of a minority will result in increased intergroup competition and conflict. The evidence also suggests, however, that when the proportion of female faculty reached a threshold of about $35-40 \%$, turnover among women began to decline. The proportion of women had a negligible or negative impact on turnover among male faculty. The authors discuss the implications of this research for the implementation of affirmative action policies.
\end{abstract}

A ffirmative action policies in higher education institutions rest on the basic premise that "a court order to "cease and desist' from some harmful activity may not be sufficient to undo the harm already done or even to prevent additional harm as the result of a pattern of events set in motion by the previous illegal activity" (Sowell 1976:161). Such policies are intended to reduce job and occupational segregation that presumably are the result of past dis-

* Pamela Tolbert is an Associate Professor in the Department of Organizational Behavior in the School of Industrial Relations at Cornell University; Tal Simons is a Lady Davis Postdoctoral Fellow in the Business School at Hebrew University; and Alice Andrews and Jaehoon Rhee are Ph.D. candidates in the Department of Organizational Behavior, School of Industrial Relations, Cornell. The authors thank Eleanor Bell, Ronald Ehrenberg, Solomon Polachek, and participants in the Role Models in Education Conference at Cornell University for comments and suggestions, and Steve Andrews and Dan Hoskens for very helpful on-the-spot consulting. crimination in two ways: first, by creating a more favorable social environment for female and minority faculty, especially in fields in which they have historically been underrepresented; and second, by attracting more female and minority students to such fields. With respect to the latter, the expectation is that female and minority faculty will serve both as direct role models and, more generally, as signals to aspiring graduate and undergraduate students of opportunities within the field (Task Force on Women, Minorities, and the Handicapped 1989). However, the mere presence of women and minorities on college faculties may not, in itself, result in substantially greater enrollments of female and

All data sources are in the public domain. A list of departments and copies of computer programs used in these analyses are available from Pamela Tolbert, N.Y. State School of Industrial and Labor Relations, Cornell University, Ithaca, NY 14853. 
minority students. The viability of female and minority college faculty members as role models and signals is likely to be affected by the conditions of their employment-the types of positions held, the level of support evinced by majority colleagues and students, the stability of employment, and so forth.

That consideration, in turn, raises the issue of whether increasing the representation of women and minorities in organizations and work groups does indeed produce a more favorable social environment for them. This notion, which formed the basis of the earliest mandates for desegregation, is predicated on an array of studies conducted in the 1950 s and 1960 s indicating that social contact between members of minority and majority status groups contributed to a general reduction in prejudice and discrimination (see Cook 1979; Pettigrew 1986). However, contemporary analyses of demographic diversity in work groups have produced more mixed findings on the effect of diversity, suggesting that in some instances the relative expansion of a minority may have a negative impact on group relations (for example, South et al. 1982, 1987; Tsui et al. 1992).

In this study, we address this issue by examining the impact of variations in the relative size of a minority group on intergroup relations, using turnover rates as a behavioral indicator of such relations. Specifically, we draw on two dominant, opposing theoretical perspectives on group proportions to derive hypotheses about the effects of group gender composition on turnover, and test these hypotheses using data collected from a sample of 50 academic departments over a 12-year period. Although there has been a proliferation of organizational research on individual and organizational consequences of variations in the gender composition of work groups in recent years, the bulk of this research has focused on attitudinal outcomes (for example, job satisfaction, job commitment, and perceptions of social isolation). The relatively few studies that have focused on more objective, behavioral outcomes, such as salary levels and job segregation (Talbert and Bose 1977; Fox 1985), have typically relied on cross-sectional data; ascertaining the direction of causality in such studies is often very difficult. And although a number of recent studies have examined the effect of various aspects of group demography on turnover (Wagner et al. 1984; O'Reilly et al. 1989; Jackson et al. 1991), none of this research has focused specifically on the impact of gender composition. Thus, the research reported here both extends previous studies of the effects of gender composition on work group relations and contributes to contemporary research on the impact of group composition on turnover.

\section{Group Proportions and Intergroup Relations: Theories and Evidence}

\section{Social Contact Theory}

Growing out of post-World War II research on sources of racial prejudice and conflict, social contact theory is predicated on the assumption that social prejudice is most likely to flourish when cross-group interactions are low. According to the general logic of this approach, the more individuals interact with members of other social groups, the more likely they are to receive evidence disconfirming the validity of out-group stereotypes. Such experiences undermine prejudicial attitudes, and thus reduce the propensity to discriminate. (See Allport [1954] for a classic statement of this theoretical perspective, and Hewstone and Brown [1986] for a contemporary summary of derivative work.)

Hence, higher rates of cross-group interaction should be associated with more harmonious intergroup relations. Since opportunities for cross-group interaction increase as groups become more similar in size, ceteris paribus (Blau 1977), this perspective suggests that intergroup relations will become more positive as group proportions approach equality and, in particular, that a relatively large minority will face a more favorable social environment than a relatively small one. Although research in this tradition has identified a number of 
progressively limiting scope conditions (Hewstone and Brown 1986), this framework continues to serve as a major theoretical foundation for studies of group demography.

One of the most notable examples of the application of social contact theory to group gender composition is provided by Kanter's (1977) ethnographic analysis of work groups in a large corporation. Based on her observations, Kanter posited a number of perceptual processes and behaviors as characteristic of majority members in "skewed groups," groups in which minorities represent $15 \%$ or less of the total membership. These processes produce counterpart attitudes and reactions among minority members of such groups.

The first process involves an intense awareness and scrutiny of individual minority members by the majority. Reciprocally, this results in a heightened sense of performance pressure among the minority. The second process entails increasing solidarity among the majority, whose commonalities are highlighted by contrasts between minority and majority members. Among the minority, the outcome of this process is increased social isolation. Finally, the third basic process rests on the existence of cultural stereotypes. Kanter argues that majority members in skewed groups are particularly prone to rely on stereotypes when interacting with minority members, and that minorities' normal behavior is distorted by efforts to cope with such type-casting. She discusses a range of such coping behaviors, from excessive conformity to stereotypes to extreme stereotype-breaking behavior.

Thus, Kanter's analysis implies that the initial entry of women into traditionally male-dominated jobs and work groups typically will result in a decline in the quality of group relations, and specifically, in an unfavorable work environment for women. Drawing on the logic of social contact theory, however, she suggests that the social dynamics associated with skewed groups should be largely eliminated as the proportion of women in a work group increases. As their relative numbers expand, women become both less visible as a group and more individuated to male colleagues.

Various empirical studies focusing on groups' gender composition have provided evidence consonant with these predictions. Research by Spangler et al. (1978), for example, comparing two law schools with substantial differences in the ratio of female to male students, showed that women in the school with a small proportion of women scored significantly higher on measures of performance pressure and social isolation than their counterparts in the school with a more balanced sex ratio. Similarly, studies by Segal (1962) of male nurses, and by Wolman and Frank (1975) of small work groups of professionals, also found a negative relation between minority group size and the level of social isolation experienced by minority members. In the same vein, lzraeli's study (1983) of women on labor union committees in Israel indicated that women on committees with relatively few women were much more likely to feel constrained by the role of being a "women's representative" and personally less influential than women on committees with a higher proportion of women.

\section{Competition Theory}

At the same time, empirical evidence also exists for an alternative theoretical perspective, one that posits very different effects of group proportions on group relations. In brief, competition theory links increases in the proportionate size of a minority group to increases in the level of intergroup hostility and conflict.

This perspective is premised on two assumptions: first, that members of socially defined groups compete collectively for control of scarce and desirable resources; and second, that group size is often determinative of the outcomes of such competition. Hence, when a minority group is relatively small, its members are unlikely to be seen by the majority as a threat to their control of social resources. However, as the proportionate size of a minority group expands, the perception of threat also rises, leading to increasing hostility toward the 
minority by majority members, and to discriminatory actions designed to protect the majority's control of resources (Blalock 1957, 1967; Bonacich 1972).

Elaborating on the logic of this perspective, Blalock (1967) posited a curvilinear relationship between minority group size and negative social outcomes for minorities, based on the assumption that increases in minority group size ultimately contribute to the ability of minorities to exert countervailing power against the majority. Thus, once a minority group expands to some threshold level, the negative consequences of increases in proportions should be reversed. In contrast to Kanter's arguments, then, this perspective suggests that increases in the proportion of women in a work group should result in progressively worse intergroup relations in general, and a less favorable social environment for women in particular, at least up to some proportional threshold.

While much of the research supporting this perspective has been based on studies focusing on the racial composition of groups (see, for example, Reed 1972; Brown and Fuguitt 1972; Frisbie and Neidert 1977; Beck and Tolnay 1990), a number of studies of gender composition have also yielded supportive findings. For example, using data from six departments in a federal agency, South et al. (1987) found that the amount of support from male co-workers reported by female employees decreased significantly with increases in the proportion of women in a department. Relatedly, a variety of studies have documented a negative relation between male employees' expressed satisfaction with their work and the proportion of women in their work group (Wharton and Baron 1987; Tsui et al. 1992; Allmendinger and Hackman 1993), a finding that is consistent with the postulated association between levels of intergroup hostility and minority group size.

More behaviorally based, albeit indirect evidence is provided by a study of Israeli universities by Toren and Kraus (1987), demonstrating a strong relationship between the proportion of women in academic departments and the level of dispar- ity between the ranks held by male and female faculty. Similarly, research by Pfeffer and Davis-Blake (1987) documented a decline in college administrators' salaries as the proportion of women in administration increased, up to about $40 \%$ women, at which point the decline leveled off.

\section{Changes in the Gender Composition of Academic Departments}

Academic departments possess a number of characteristics that make them well suited for the exploration of predictions derived from the theoretical perspectives described above. First, these departments represent work groups that normally are characterized by a high level of face-to-face interaction among members. Thus, the sorts of social dynamics suggested by social contact theory should have ample opportunity to develop. Second, members are likely to share superordinate goals, created both by collective responsibility for managing day-to-day tasks of the department (for example, staffing courses, admitting and credentialing students) and by the individual and collective advantages to be gained by maximizing the department's status (see Crane 1965; Rosenfeld and Jones 1986; Allison and Long 1990; Long 1992; Long et al. 1993). That characteristic of academic departments is important because the presence of superordinate goals has been identified as one of the key scope conditions of social contact theory (Hewstone and Brown 1986). Finally, academic departments typically exercise a large measure of control over personnel assignments, including the admission of new members and the allocation of existing members to higher ranks. Such personnel assignments are often represented as a scarce resource, one that may become the object of competition.

Moreover, many academic departments, particularly in the social sciences, have experienced notable shifts in their gender composition in recent decades, shifts that reflect the growing numbers of women in academic labor markets. In psychology, for example, the percentage of doctoral de- 
Table 1. Mean Number and Percentage of Female Faculty in Sociology Departments, by Rank and Year.

$(\mathrm{N}=50$; Standard Deviations in Parentheses)

\begin{tabular}{|c|c|c|c|c|c|c|c|c|}
\hline \multirow[b]{2}{*}{ Year } & \multicolumn{2}{|c|}{ Fulls } & \multicolumn{2}{|c|}{ Associates } & \multicolumn{2}{|c|}{ Assistants } & \multicolumn{2}{|c|}{ Total } \\
\hline & No. & $\%$ & No. & $\%$ & No & $\%$ & No & $\%$ \\
\hline 1977 & $\begin{array}{l}.30 \\
(.65)\end{array}$ & $\begin{array}{c}4.9 \\
(12.0)\end{array}$ & $\begin{array}{c}.56 \\
(.95)\end{array}$ & $\begin{array}{c}10.6 \\
(15.8)\end{array}$ & $\begin{array}{c}1.66 \\
(1.26)\end{array}$ & $\begin{array}{c}28.1 \\
(19.1)\end{array}$ & $\begin{array}{c}2.56 \\
(2.07)\end{array}$ & $\begin{array}{l}14.3 \\
(9.7)\end{array}$ \\
\hline 1978 & $\begin{array}{l}.34 \\
(.69)\end{array}$ & $\begin{array}{c}5.8 \\
(12.9)\end{array}$ & $\begin{array}{c}.54 \\
(.91)\end{array}$ & $\begin{array}{c}10.4 \\
(15.3)\end{array}$ & $\begin{array}{c}1.56 \\
(1.09)\end{array}$ & $\begin{array}{c}31.3 \\
(21.0)\end{array}$ & $\begin{array}{c}2.44 \\
(1.63)\end{array}$ & $\begin{array}{l}14.9 \\
(9.2)\end{array}$ \\
\hline 1979 & $\begin{array}{c}.38 \\
(.67)\end{array}$ & $\begin{array}{c}6.2 \\
(12.9)\end{array}$ & $\begin{array}{l}.78 \\
(.95)\end{array}$ & $\begin{array}{c}15.2 \\
(20.3)\end{array}$ & $\begin{array}{c}1.54 \\
(1.01)\end{array}$ & $\begin{array}{c}35.6 \\
(25.0)\end{array}$ & $\begin{array}{c}2.70 \\
(1.69)\end{array}$ & $\begin{array}{c}16.3 \\
(10.2)\end{array}$ \\
\hline 1980 & $\begin{array}{c}.38 \\
(.70)\end{array}$ & $\begin{array}{c}6.0 \\
(13.3)\end{array}$ & $\begin{array}{c}.80 \\
(.99)\end{array}$ & $\begin{array}{c}13.6 \\
(15.8)\end{array}$ & $\begin{array}{c}1.66 \\
(1.19)\end{array}$ & $\begin{array}{c}37.1 \\
(25.9)\end{array}$ & $\begin{array}{c}2.84 \\
(1.71)\end{array}$ & $\begin{array}{c}17.2 \\
(10.1)\end{array}$ \\
\hline 1981 & $\begin{array}{c}.42 \\
(.73)\end{array}$ & $\begin{array}{c}6.1 \\
(12.7)\end{array}$ & $\begin{array}{c}.88 \\
(.98)\end{array}$ & $\begin{array}{c}16.4 \\
(20.5)\end{array}$ & $\begin{array}{c}1.56 \\
(1.15)\end{array}$ & $\begin{array}{c}36.6 \\
(26.1)\end{array}$ & $\begin{array}{c}2.86 \\
(1.62)\end{array}$ & $\begin{array}{c}17.5 \\
(10.2)\end{array}$ \\
\hline 1982 & $\begin{array}{l}.54 \\
(.91)\end{array}$ & $\begin{array}{c}7.1 \\
(13.5)\end{array}$ & $\begin{array}{c}.90 \\
(1.02)\end{array}$ & $\begin{array}{c}15.7 \\
(17.9)\end{array}$ & $\begin{array}{c}1.40 \\
(1.18)\end{array}$ & $\begin{array}{c}35.0 \\
(23.1)\end{array}$ & $\begin{array}{c}2.84 \\
(1.58)\end{array}$ & $\begin{array}{l}17.4 \\
(9.3)\end{array}$ \\
\hline 1983 & $\begin{array}{l}.54 \\
(.89)\end{array}$ & $\begin{array}{c}6.9 \\
(13.0)\end{array}$ & $\begin{array}{c}.96 \\
(1.03)\end{array}$ & $\begin{array}{c}16.0 \\
(16.9)\end{array}$ & $\begin{array}{c}1.34 \\
(1.14)\end{array}$ & $\begin{array}{c}36.3 \\
(25.8)\end{array}$ & $\begin{array}{c}2.84 \\
(1.48)\end{array}$ & $\begin{array}{l}18.0 \\
(8.9)\end{array}$ \\
\hline 1984 & $\begin{array}{c}.58 \\
(.93)\end{array}$ & $\begin{array}{c}7.0 \\
(13.2)\end{array}$ & $\begin{array}{c}1.00 \\
(1.07)\end{array}$ & $\begin{array}{c}17.6 \\
(18.0)\end{array}$ & $\begin{array}{l}1.30 \\
(.99)\end{array}$ & $\begin{array}{c}38.5 \\
(26.4)\end{array}$ & $\begin{array}{c}2.88 \\
(1.52)\end{array}$ & $\begin{array}{l}18.1 \\
(8.6)\end{array}$ \\
\hline 1985 & $\begin{array}{c}.68 \\
(1.00)\end{array}$ & $\begin{array}{c}8.0 \\
(13.6)\end{array}$ & $\begin{array}{c}1.00 \\
(1.03)\end{array}$ & $\begin{array}{c}17.4 \\
(16.8)\end{array}$ & $\begin{array}{c}1.32 \\
(1.02)\end{array}$ & $\begin{array}{c}42.4 \\
(32.2)\end{array}$ & $\begin{array}{c}3.00 \\
(1.56)\end{array}$ & $\begin{array}{l}18.9 \\
(8.9)\end{array}$ \\
\hline 1986 & $\begin{array}{c}.80 \\
(1.12)\end{array}$ & $\begin{array}{c}8.7 \\
(13.0)\end{array}$ & $\begin{array}{c}1.06 \\
(1.11)\end{array}$ & $\begin{array}{c}19.5 \\
(18.0)\end{array}$ & $\begin{array}{c}1.28 \\
(1.03)\end{array}$ & $\begin{array}{c}44.6 \\
(29.6)\end{array}$ & $\begin{array}{c}3.12 \\
(1.72)\end{array}$ & $\begin{array}{l}19.9 \\
(9.3)\end{array}$ \\
\hline 1987 & $\begin{array}{c}.82 \\
(1.04)\end{array}$ & $\begin{array}{c}10.0 \\
(13.3)\end{array}$ & $\begin{array}{c}1.00 \\
(1.07)\end{array}$ & $\begin{array}{c}19.5 \\
(17.6)\end{array}$ & $\begin{array}{c}1.28 \\
(1.05)\end{array}$ & $\begin{array}{c}44.0 \\
(30.2)\end{array}$ & $\begin{array}{c}3.10 \\
(1.66)\end{array}$ & $\begin{array}{l}20.4 \\
(9.7)\end{array}$ \\
\hline 1988 & $\begin{array}{c}.90 \\
(1.15)\end{array}$ & $\begin{array}{c}10.3 \\
(13.4)\end{array}$ & $\begin{array}{c}1.18 \\
(1.11)\end{array}$ & $\begin{array}{c}24.0 \\
(21.3)\end{array}$ & $\begin{array}{c}1.06 \\
(1.02)\end{array}$ & $\begin{array}{c}38.7 \\
(32.6)\end{array}$ & $\begin{array}{c}3.14 \\
(1.75)\end{array}$ & $\begin{array}{c}20.6 \\
(10.7)\end{array}$ \\
\hline
\end{tabular}

Source: ASA Guide to Graduate Departments.

grees awarded to women rose from $22 \%$ in 1970 to $61 \%$ by 1991 . Similarly, over the same 20-year span, female doctorates increased from $11 \%$ to $25 \%$ in political science and government and from $5 \%$ to $20 \%$ in economics. This general trend has also affected sociology: the proportion of female doctorates rose from $19 \%$ in 1970 to nearly $50 \%$ by 1991 (Andersen et al. 1991; National Center for Education Statistics 1993).

To illustrate the impact of such changes in the distribution of women among advanced degree recipients on the representation of women in faculty positions, in Table 1 we provide descriptive data, drawn from a sample of 50 departments of sociology, on the mean numbers and percentage of female faculty members in these departments between 1977 and 1988. (Sampling procedures are described in the following section.)

Over this 12-year span, the average proportion of female faculty in these departments increased by approximately $50 \%$, rising from $14 \%$ at the beginning of the period to over $20 \%$ at the end. A fairly steady annual rate of increase is visible at all ranks, although the largest representation of women continued to be found at the assistant level even at the end of this period. However, as the relatively large standard deviations suggest, there is a considerable variation in gender composition across departments as well as within departments across time, with the total proportion of women ranging from zero to $50 \%$.

As described above, social contact and competition theories offer sharply differing predictions about the effects of such 
variations in departmental gender composition on the social environment for female faculty. One logical indicator of this environment is the rate of turnover; less favorable environments can be expected to result in higher rates of turnover by women.

Traditionally, research on turnover has focused on individual-level determinants, such as race, sex, and job attitudes (Mowday et al. 1982); concern with specifying effects of the employment context, including such factors as organizational demography, is comparatively recent (Schneider 1983; Wagner et al. 1984; O'Reilly et al. 1989; Tsui et al. 1992). Although studies that have investigated the impact of demography on turnover have typically focused on such aspects as age and tenure heterogeneity, both the theoretical logic and the findings of these studies are consistent with the approach taken here. Group composition has been theorized to affect patterns of communication and levels of group cohesion, thus affecting rates of turnover. Most studies have found a positive association between heterogeneity measures and turnover.

A social contact approach suggests that women in departments with a relatively small proportion of women are likely to experience higher levels of social isolation and to have their performance subject to more intensive scrutiny by male colleagues than their counterparts in departments with a larger proportion of women; thus, declining levels of both voluntary and involuntary turnover should accompany increases in women's relative numbers in departments.

In contrast, competition theory leads to the prediction of a curvilinear relationship between turnover and proportion of women. As the proportion of women in a department increases, so should male faculty's perception that their traditional exercise of control over departmental resources is threatened. This perception, in turn, should to lead to attitudes and behaviors that create an increasingly unfavorable environment for female faculty, and thus to a greater likelihood of turnover. As the proportion of women in a department reaches some threshold level, however, the effects on turnover should be reversed, reflecting the greater power and more favorable social environment associated with increasing group size.

\section{Sample, Data, and Methods}

\section{Sampling Procedures}

To investigate these hypotheses, we collected demographic data on 50 sociology departments offering graduate degree programs between 1977 and 1988. The sampling frame consisted of all departments in the United States that were listed in the Guide to Graduate Departments, an annual publication of the American Sociological Association. Departments that were missing for two or more years from the Guide during the time period of the study were eliminated, and a random sample of departments was then drawn.

A major advantage of this data source is that it provides detailed information on the demographic composition of similar types of organizational work groups (by providing lists of current faculty members and their ranks) across a large number of organizations and over an extended period of time. This type of comparative data, which is necessary for examination of the dynamics of demographic change, is relatively rare.

One potential problem in using such archival data is inaccuracy in the lists of faculty members-listings may reflect accidental omissions, failures to delete members who have left, and so on. We minimized such inaccuracies through the following data collection procedures. We constructed a matrix for each department, with each person reported as a faculty member listed on a separate row and with columns indicating specific years. Each cell in the matrix was marked with a check if a person was reported on the faculty in a given year, or left blank if the person was not reported. If a person previously listed on the faculty was not listed for one or two years, but was then listed in subsequent years, we did not treat that as an incidence of turnover. If a person was listed on the faculty in two sepa- 
rate departments in a given year (which occasionally occurred when a department did not delete a faculty member who had moved), we examined the pattern of employment in the following years to determine with which department he or she remained. If individuals remained at a new department, the year they were first listed there was treated as the year they left their department of origin; if they did not remain, it was not treated as an incidence of turnover.

\section{Measures}

Following these procedures, six variables were created for each department each year, indicating the number of faculty, at each rank and by gender, who left the department. ${ }^{1}$ The numbers of departures at associate and full levels were combined to create a measure of turnover for women and for men at tenured rank; and the number across all three ranks was summed to produce overall measures of women's turnover and men's turnover. Because of the small number of women in most departments, the turnover measures for women varied from zero to one in any given year, with very few exceptions. As a consequence, we converted each turnover measure to a

\footnotetext{
${ }^{1}$ In cases in which a person's sex could not easily be determined by the name listed, we took a number of steps. The first was to ask other sociologists that we knew if they were familiar with the individual. Because sociology is a relatively small discipline and the graduate departments listed in the Guide consist of a highly visible subset of all sociology departments, this procedure allowed us to classify many of the ambiguous names. For the remaining 22 names, we used individuals' areas of specialization to make informed guesses about appropriate classification. We were able to check on a dozen of these names, and found we were wrong on four, for whom we corrected our classification. For the others-most of whom had left the department in the early to mid- $80 \mathrm{~s}$ - we were not able to find a contact person currently with the department who could identify the person as male or female. Since the total number of faculty in the departments used in this study ranged from 790 to 877 , errors created by misclassification of this remaining set are very unlikely to substantially affect the analyses.
}

dummy variable, with " 1 " representing the occurrence of turnover in a department. ${ }^{2}$

Since some departments in given years had either no female faculty at all or none at specified ranks, the potential problem of sample selection bias existed. To deal with this possibility, we followed two-stage estimation procedures described by Heckman (1979) and Berk (1983), involving construction of variables measuring a department's predicted probability of having female faculty at specific ranks, and inclusion of these variables in models estimating turnover probabilities. The model used to estimate the predicted probability of a department having female faculty included two measures of departmental size, total number of faculty and total number of graduate students, the size of the metropolitan area in which a given institution was located according to the 1980 census, a dummy variable indicating whether a department awarded Ph.D. degrees, and a series of dummy variables to capture trend effects. The results of the logistic regressions used to construct the sample selection measure are shown in Table $2 .^{3}$

Key predictor variables in our main analyses included a lagged measure of the proportion of women among full-time faculty members and the quadratic form of this variable. The latter was included to capture curvilinear effects suggested by Blalock's theoretical arguments. ${ }^{4}$ As an

\footnotetext{
${ }^{2}$ Because the absolute number of men was higher than that of women in all departments, the range of male faculty leaving departments was also larger. To be consistent with the analyses of turnover among female faculty, we used logistic models with dummy measures as dependent variables in our analyses of turnover among men. However, ordinary least squares models for turnover among men yielded essentially the same substantive results as the logistic models.

${ }^{3}$ Berk (1983) has shown that estimation procedures using probit and logistic analyses yield the same substantive results. We also found this in our own analyses, and since estimation with logistic regression is procedurally simpler, we used the latter.

${ }^{4} \mathrm{~A}$ model with a cubic term was also examined, based on the notion that processes described by social contact and competition theories could both be operative-initial support resulting from increased con-
} 
Table 2. Regression Coefficients from Models Predicting Log-Odds of Having Female Faculty Members, 1978-1988. $(\mathrm{N}=550$; Standard Errors in Parentheses)

\begin{tabular}{|c|c|c|c|}
\hline $\begin{array}{l}\text { Independent } \\
\text { Variable }\end{array}$ & $\begin{array}{c}\text { All } \\
\text { Ranks }\end{array}$ & $\begin{array}{l}\text { Assistant } \\
\text { Rank }\end{array}$ & $\begin{array}{l}\text { Tenure } \\
\text { Rank }\end{array}$ \\
\hline Intercept & $\begin{array}{l}-.637 \\
(.788)\end{array}$ & $\begin{array}{l}-.555 \\
(.525)\end{array}$ & $\begin{array}{c}-.1 .728 * * * \\
(.455)\end{array}$ \\
\hline $\begin{array}{l}\text { Total No. } \\
\text { of Faculty }\end{array}$ & $\begin{array}{l}.172^{* * * *} \\
(.049)\end{array}$ & $\begin{array}{l}.128^{* * * *} \\
(.022)\end{array}$ & $\begin{array}{l}.106 * * * \\
(.019)\end{array}$ \\
\hline $\begin{array}{l}\text { Total No. } \\
\text { of Graduate } \\
\text { Students }\end{array}$ & $\begin{array}{l}-.051 \\
(.042)\end{array}$ & $\begin{array}{l}.005 \\
(.023)\end{array}$ & $\begin{array}{c}-.034^{+} \\
(.020)\end{array}$ \\
\hline $\begin{array}{l}\text { Population in } \\
\text { Metropolitan } \\
\text { Area }\end{array}$ & $\begin{array}{c}.008 * \\
(.004)\end{array}$ & $\begin{array}{l}-.005^{*} \\
(.002)\end{array}$ & $\begin{array}{l}.010 * * \\
(.003)\end{array}$ \\
\hline Award Ph.D. & $\begin{array}{l}2.125 * * * \\
(.58)\end{array}$ & $\begin{array}{l}.807 * * \\
(.267)\end{array}$ & $\begin{array}{l}-.122 \\
(.259)\end{array}$ \\
\hline Year 79 & $\begin{array}{l}.163 \\
(.762)\end{array}$ & $\begin{array}{c}.189 \\
(.593)\end{array}$ & $\begin{array}{l}.664 \\
(.442)\end{array}$ \\
\hline Year 80 & $\begin{array}{l}.521 \\
(.820)\end{array}$ & $\begin{array}{l}.198 \\
(.595)\end{array}$ & $\begin{array}{l}.434 \\
(.440)\end{array}$ \\
\hline Year 81 & $\begin{array}{c}.452 \\
(.830)\end{array}$ & $\begin{array}{l}.505 \\
(.578)\end{array}$ & $\begin{array}{r}.790^{+} \\
(.449)\end{array}$ \\
\hline Year 82 & $\begin{array}{c}.905 \\
(.934)\end{array}$ & $\begin{array}{l}.466 \\
(.581)\end{array}$ & $\begin{array}{l}.675 \\
(.451)\end{array}$ \\
\hline Year 83 & $\begin{array}{c}1.933 \\
(1.170)\end{array}$ & $\begin{array}{c}.382 \\
(.576)\end{array}$ & $\begin{array}{l}1.320 * * \\
(.468)\end{array}$ \\
\hline Year 84 & $\begin{array}{c}1.761 \\
(1.159)\end{array}$ & $\begin{array}{c}.419 \\
(.574)\end{array}$ & $\begin{array}{l}1.571^{* * * *} \\
(.484)\end{array}$ \\
\hline Year 85 & $\begin{array}{c}.946 \\
(.928)\end{array}$ & $\begin{array}{c}.791 \\
(.561)\end{array}$ & $\begin{array}{l}1.522 * * \\
(.489)\end{array}$ \\
\hline Year 86 & $\begin{array}{l}.973 \\
(.927)\end{array}$ & $\begin{array}{l}1.086 * \\
(.550)\end{array}$ & $\begin{array}{l}1.847 * * * \\
(.513)\end{array}$ \\
\hline Year 87 & $\begin{array}{c}.927 \\
(.932)\end{array}$ & $\begin{array}{c}.836 \\
(.557)\end{array}$ & $\begin{array}{l}1.856^{* * * *} \\
(.514)\end{array}$ \\
\hline Year 88 & $\begin{array}{c}1.838 \\
(1.165)\end{array}$ & $\begin{array}{c}.440 \\
(.572)\end{array}$ & $\begin{array}{l}1.909 * * * \\
(.513)\end{array}$ \\
\hline$-2 \log \mathrm{L}$ & 165.54 & 492.63 & 560.81 \\
\hline Model Chi Sq. & $43.86 * * *$ & $76.67 * * *$ & $89.54 * * *$ \\
\hline
\end{tabular}

+Statistically significant at the .10 level; *at the .05 level; **at the .01 level; ***at the .001 level.

Source: ASA Guide to Graduate Departments.

alternative to the quadratic specification, we also included a measure of the percentage of women among tenured faculty on

tact decreases turnover, but competition processes ultimately increase it until a threshold proportion is reached. However, the coefficients in this model were nonsignificant and quite unstable; thus, pursuing this sort of theoretical synthesis did not seem appropriate with our data. the assumption that this might be a better indicator of women's influence in a department. In addition, we included a number of control variables in each of the analyses: a lagged measure of the total number of male or female faculty at a given rank in a department (depending on whether the analysis examined turnover among men or women), a measure of departmental prestige, a measure of institutional control, a lagged annual measure of the proportion of Ph.D. degrees awarded to men, and a measure to correct for sample selection bias.

The measure of total number of women (or men) was included since, net of all other factors, the statistical probability of a department experiencing turnover necessarily increases as the number of faculty increases. We controlled for prestige based on the assumption that more prestigious departments would be likely to hold higher standards for promotion and, as a consequence, to have potentially higher rates of turnover. The ratings assigned departments by the National Research Council, based on a 1981 reputational survey, were used to measure prestige; missing values were assigned through regression estimates. Since public institutions are typically heavily dependent on state and federal funding, they are apt to be more sensitive to affirmative action pressure (Edelman 1992); thus, the inclusion of the measure of institutional control was premised on the notion that such affirmative action pressure might indirectly affect turnover rates. Control was represented by a dummy variable, coded " 1 " for public institutions. The measure of the proportion of sociology Ph.D.'s annually awarded to men, based on data in the Digest of Educational Statistics (National Center for Education Statistics 1993), was used as a proxy for the availability of women in the labor market, since tighter labor markets for female faculty might increase the value of women to departments and thus affect turnover rates.

Descriptive statistics, including means, standard deviations, and variable intercorrelations, can be found in the Appendix. 
Table 3. Logistic Regression Coefficients

from Models of Turnover Among All Female Faculty, 1978-1988.

$(\mathrm{N}=518$; Standard Errors in Parentheses)

\begin{tabular}{lcccccccc}
\hline Independent Variable & Model 1 & Model 1a & Model 2 & Model 2a & Model 3 & Model 3a & Model 4 & Model 4a \\
\hline Intercept & .140 & -.524 & -3.152 & -2.537 & 1.290 & -.662 & -.864 & -.1 .953 \\
& $(2.925)$ & $(1.391)$ & $(3.126)$ & $(1.548)$ & $(2.972)$ & $(1.433)$ & $(3.191)$ & $(1.583)$ \\
Pct. Female Faculty* & -.020 & -.018 & $.175^{* *}$ & $.172^{* *}$ & .028 & .031 & $.144^{*}$ & $.150^{*}$ \\
& $(.019)$ & $(.018)$ & $(.066)$ & $(.064)$ & $(.023)$ & $(.022)$ & $(.068)$ & $(.066)$ \\
Pct. Female & - & - & $-.004^{* *}$ & $-.004^{* *}$ & - & - & $-.002^{*}$ & $-.002^{*}$ \\
Faculty Sq. & & & $(.001)$ & $(.001)$ & & & $(.001)$ & $(.001)$ \\
Pct. Tenure Rank & - & - & - & - & $-.068^{* * *}$ & $-.067^{* * *}$ & $-.058^{* * *}$ & $-.057^{* * *}$ \\
Female Faculty" & & & & & $(.016)$ & $(.016)$ & $(.016)$ & $(.016)$ \\
Total No. Female & $.406^{* * *}$ & $.395^{* * *}$ & $.293^{* *}$ & $.304^{* *}$ & $.502^{* * *}$ & $.466^{* * *}$ & $.415^{* * *}$ & $.393^{* * *}$ \\
Faculty" & $(.105)$ & $(.095)$ & $(.111)$ & $(.099)$ & $(.114)$ & $(.102)$ & $(.121)$ & $(.107)$ \\
Prestige & -.023 & -.023 & -.024 & -.024 & -.021 & -.021 & -.022 & 0.022 \\
& $(.015)$ & $(.015)$ & $(.015)$ & $(.015)$ & $(.015)$ & $(.015)$ & $(.015)$ & $(.015)$ \\
Public Control & $-.806^{* *}$ & $-.797^{* *}$ & $-.751^{* *}$ & $-.761^{* *}$ & $-.800^{* *}$ & $-.774^{* *}$ & $0.758^{* *}$ & $0.742^{* *}$ \\
& $(.266)$ & $(.263)$ & $(.267)$ & $(.264)$ & $(.280)$ & $(.277)$ & $(.279)$ & $(.275)$ \\
Pct. Ph.D.'s Awarded & -.001 & .001 & .009 & .008 & -.010 & -0.007 & -0.003 & -.001 \\
to Men & $(.019)$ & $(.018)$ & $(.019)$ & $(.018)$ & $(.019)$ & $(.019)$ & $(.020)$ & $(.019)$ \\
Selection Coefficient & -.618 & - & -.549 & - & -1.807 & - & -.963 & - \\
& $(2.392)$ & & $(2.427)$ & & $(2.400)$ & & $(2.444)$ & \\
-2 Log L & 524.97 & 525.04 & 513.99 & 514.04 & 504.57 & 505.12 & 500.90 & 501.05 \\
Model Chi Sq. & $33.38^{* * *}$ & $33.31^{* * *}$ & $44.36^{* * *}$ & $44.31^{* * *}$ & $53.78^{* * *}$ & $53.23^{* * *}$ & $57.45^{* * *}$ & $57.30^{* * *}$ \\
\hline
\end{tabular}

'Statistically significant at the .10 level; *at the .05 level; **at the .01 level; ***at the .001 level.

ane year lagged measure.

Source: ASA Guide to Graduate Departments.

\section{Analysis}

Logistic regression models were used to estimate the effects of predictor variables on turnover, as an approximation to discrete-time hazard models. Logistic regression is a conventional means of estimating models for event data (Allison 1984; Yamaguchi 1991), especially when evidence indicates a lack of time dependence in the hazard rates. Simple baseline measures of the hazard rates for turnover did not indicate the presence of time dependence in our data.

\section{Findings}

Table 3 presents the results for the analyses of turnover among women at all ranks in a department. Models 1, 2, 3, and 4 include a sample selection term; 1a, 2a, 3a, and $4 \mathrm{a}$ are counterpart models excluding this term. Although the coefficient of the selection term is negative, suggesting that unobserved factors causing departments to hire female faculty also contribute to a reduction in women's turnover, it is nonsignificant in all instances, and the substantive results of the analyses are not affected by its inclusion.

Consistent with predictions of social contact theory, in models 1 and 1a, the coefficient for percent women is negative. It is, however, nonsignificant, and when the quadratic term is included in models 2 and 4 , the sign of the coefficient changes and is significant. The results of the latter models suggest that as the proportion of women in a department increases, so does the likelihood of turnover, at least until the proportion reaches a threshold point. Note that these effects occur net of the influence of having a larger absolute number of women on the faculty.

Calculated probabilities of turnover, based on the equation represented in model 4 , indicate that the threshold point is between $35 \%$ and $40 \%$. However, in less than 
Table 4. Logistic Regression Coefficients

from Models of Turnover Among Female Assistant Professors, 1978-1988.

( $\mathrm{N}=435$; Standard Errors in Parentheses)

\begin{tabular}{lcccccccc}
\hline Independent Variable & Model 1 & Model 1a & Model 2 & Model 2a & Model 3 & Model 3a & Model 4 & Model 4a \\
\hline Intercept & .586 & .104 & -.340 & -.826 & 1.763 & .416 & .879 & -.513 \\
& $(1.623)$ & $(1.563)$ & $(1.807)$ & $(1.722)$ & $(1.788)$ & $(1.620)$ & $(2.006)$ & $(1.778)$ \\
Pct. Female Faculty" & -.008 & -.002 & $.074^{*}$ & $.087^{*}$ & .057 & .019 & $.015^{*}$ & $.068^{*}$ \\
& $(.010)$ & $(.004)$ & $(.034)$ & $(.051)$ & $(.037)$ & $(.013)$ & $(.007)$ & $(.033)$ \\
Pct. Female & - & - & $-.002^{*}$ & $-.002^{*}$ & - & - & $-.001 *$ & $-.002^{*}$ \\
Faculty Sq. & & & $(.001)$ & $(.001)$ & & & $(.000)$ & $(.001)$ \\
Pct. Tenure Rank & - & - & - & - & -.041 & .017 & -.037 & -.016 \\
Female Faculty* & & & & & $(.026)$ & $(.010)$ & $(.026)$ & $(.022)$ \\
Total No. Female & $.811^{* * *}$ & $.734^{* * *}$ & $.749^{* * *}$ & $.678^{* * *}$ & $1.078^{* * *}$ & $.814^{* * *}$ & $1.000^{* * *}$ & .755 \\
Assistants & $(.160)$ & $(.141)$ & $(.168)$ & $(.146)$ & $(.237)$ & $(.179)$ & $(.249)$ & $(.183)$ \\
Prestige & -.019 & $-.025^{*}$ & -.022 & $-.028^{*}$ & -.022 & $-.028^{+}$ & -.024 & $-.031^{*}$ \\
& $(.016)$ & $(.015)$ & $(.016)$ & $(.015)$ & $(.016)$ & $(.016)$ & $(.017)$ & $(.016)$ \\
Public Control & $-.881^{* *}$ & $-.926^{* *}$ & $-.876^{* *}$ & $-.912^{* *}$ & $-.1 .022^{* * *}$ & $-.999^{* * *}-.1 .006^{* * *}$ & $-.982^{* * *}$ \\
& $(.301)$ & $(.298)$ & $(.299)$ & $(.296)$ & $(.315)$ & $(.314)$ & $(.314)$ & $(.312)$ \\
Pct. Ph.D.'s Awarded & -.014 & -.017 & -.010 & -.012 & -.014 & -.018 & -.011 & -.013 \\
to Men & $(.021)$ & $(.021)$ & $(.021)$ & $(.021)$ & $(.021)$ & $(.021)$ & $(.021)$ & $(.021)$ \\
Selection Coefficient & -.1 .229 & - & -.1 .029 & - & $-2.329^{*}$ & - & -2.049 & - \\
& $(1.140)$ & & $(1.154)$ & & $(1.322)$ & & $(1.351)$ & \\
-2 Log L & 415.05 & 416.19 & 413.66 & 414.44 & 412.64 & 415.64 & 409.70 & 410.94 \\
Model Chi Sq. & $46.63^{* * *}$ & $45.49 * * *$ & $48.02^{* * *}$ & $47.24^{* * *}$ & $49.04^{* * *}$ & $46.04^{* * *}$ & $49.98^{* * *}$ & 47.74
\end{tabular}

'Statistically significant at the .10 level; *at the .05 level; **at the .01 level; ***at the .001 level.

"One year lagged measure.

Source: ASA Guide to Graduate Departments.

$5 \%$ of the departments in our sample $(\mathrm{N}=$ 26) did women constitute a third or more of the faculty. Thus, although these results are consistent with the logic of competition theory, problems of limited sample range require that they be interpreted with caution. If percent of women among tenured faculty, shown in models 3 and 4 , is interpreted as an alternative measure of women's power in a department, the strong negative coefficient on this variable is also consistent with competition theory. However, since tenured women are less likely to leave a department, the causal effect of this variable on net likelihood of turnover among women is ambiguous. In sum, while the findings that increases in the proportion of women in a department led to increases in the likelihood of women's turnover are consistent with competition theory, the evidence of a reduction in turnover with the increasing power of female faculty, while also in line with this theoretical perspective, is less conclusive. ${ }^{5}$

It could be inferred from the general logic of competition theory that involuntary turnover is most likely to be the immediate product of an increasing proportion of women in a department. One way for the majority group to protect its control of resources is simply to reduce the number of women, and untenured faculty are most vulnerable to such efforts. To investigate this possibility, we examined turnover among associate and full professors and assistant professors separately. ${ }^{6}$ Although

\footnotetext{
${ }^{5}$ See also Blank (1991) and Broder (1993) on the debate over whether women tend to act as the sort of self-conscious minority group to which Blalock's theory applies.

${ }^{6}$ As in most research on turnover, we cannot completely distinguish between voluntary and involuntary turnover with our data. Presumably, turnover at
} 
Table 5. Logistic Regression Coefficients from Models of Turnover Among Tenure Rank Female Professors, 1978-1988.

$(\mathrm{N}=380$; Standard Errors in Parentheses)

\begin{tabular}{lcccccccc}
\hline Independent Variable & Model 1 & Model 1a & Model 2 & Model 2a & Model 3 & Model 3a & Model 4 & Model 4a \\
\hline Intercept & -.036 & -3.619 & -.1 .471 & $-5.135^{+}$ & 1.121 & -3.507 & .099 & $-4.875^{+}$ \\
& $(3.177)$ & $(2.415)$ & $(3.416)$ & $(2.702)$ & $(3.390)$ & $(2.484)$ & $(3.721)$ & $(2.792)$ \\
Pct. Female Faculty" & -.005 & .014 & .143 & .163 & .036 & .041 & .119 & .156 \\
& $(.028)$ & $(.026)$ & $(.110)$ & $(.111)$ & $(.039)$ & $(.039)$ & $(.110)$ & $(.111)$ \\
Pct. Female & - & - & -.003 & -.003 & - & - & -.002 & -.003 \\
Faculty Sq. & & & $(.002)$ & $(.002)$ & & & $(.002)$ & $(.002)$ \\
Pct. Tenure Rank & - & - & - & - & -.067 & -.040 & -.046 & -.017 \\
Female Faculty & & & & & $(-.044)$ & $(.041)$ & $(.049)$ & $(.045)$ \\
Total No. Tenure & $.365^{*}$ & .202 & $.362^{*}$ & .202 & $.563 * *$ & $.302^{+}$ & $.501 *$ & .244 \\
Rank Female Faculty" & $(.173)$ & $(.150)$ & $(.140)$ & $(.146)$ & $(.214)$ & $(.182)$ & $(.224)$ & $(.184)$ \\
Prestige & .024 & .015 & .019 & .010 & .015 & .009 & .014 & .008 \\
& $(.026)$ & $(.026)$ & $(.027)$ & $(.027)$ & $(.027)$ & $(.027)$ & $(.028)$ & $(.027)$ \\
Public Control & .037 & -.083 & -.024 & -.132 & .030 & -.110 & -.013 & -.139 \\
& $(.443)$ & $(.433)$ & $(.448)$ & $(.436)$ & $(.457)$ & $(.441)$ & $(.456)$ & $(.439)$ \\
Pct. Ph.D.'s Awarded & -.038 & -.004 & -.035 & -.001 & -.045 & -.003 & -.041 & -.001 \\
to Men & $(.037)$ & $(.031)$ & $(.037)$ & $(.032)$ & $(.038)$ & $(.032)$ & $(.038)$ & $(.031)$ \\
Selection Coefficient & $-2.912^{*}$ & - & $-2.916^{+}$ & - & $-3.662 *$ & - & -3.423 & - \\
& $(1.571)$ & & $(1.577)$ & & $(1.652)$ & & $(1.670)$ & \\
-2 Log L & 202.31 & 205.69 & 200.06 & 203.44 & 199.84 & 204.72 & 199.12 & 203.30 \\
Model Chi Sq. & 7.60 & 4.21 & 9.85 & 6.46 & 10.07 & 5.19 & 10.79 & 6.60
\end{tabular}

'Statistically significant at the .10 level; *at the .05 level; **at the .01 level; ***at the .001 level.

ane year lagged measure.

Source: ASA Guide to Graduate Departments.

rank is only a proxy for tenure status, very few sociology departments promote faculty to associate rank without granting tenure.

Table 4 shows the results of analyses of turnover among female assistant professors. Again in line with predictions from competition theory, increases in the percentage of women are generally associated with an increasing likelihood of turnover, although, surprisingly, the magnitude of this effect is weaker than in the analyses of overall turnover of female faculty. The coefficient on percent women attains significance only in models 2 and 4 , which include the squared term. The quadratic term is also significant in both models, but calculation of predicted probabilities based on model 4 indicates that increases in the proportion of women begin to reduce turn-

tenured levels is more likely to reflect voluntary action, although age-based retirement policies also account for some turnover at this level. over only when the overall proportion exceeds $45 \%$. Since less than $1 \%$ of the departments in our sample achieve this proportion, the finding of curvilinear effects again must be interpreted very cautiously. In addition, in models 3 and 4, the coefficient on percent women at tenured ranks is nonsignificant, in contrast to the significant effects found in analyses for turnover among all female faculty.

Table 5 presents analyses of turnover among female tenure rank faculty. Although the same directional pattern of effects for the gender composition measures is found at this level, none of the coefficients attains significance. Notably, in these models the coefficient on the sample selection variable becomes significant, suggesting that conditions that lower departments' probabilities of having tenure level female faculty are likely to contribute to higher levels of turnover among women at this level. 
Table 6. Logistic Regression Coefficients

from Models of Turnover Among All Male Faculty, 1978-1988.

( $\mathrm{N}=518$; Standard Errors in Parentheses)

\begin{tabular}{lcccccccc}
\hline Independent Variable & Model 1 & Model 1a & Model 2 & Model 2a & Model 3 & Model 3a & Model 4 & Model 4a \\
\hline Intercept & 4.259 & 1.220 & 3.131 & .387 & $4.284^{*}$ & 1.222 & 2.972 & .348 \\
& $(2.300)$ & $(1.119)$ & $(2.372)$ & $(1.193)$ & $(2.316)$ & $(1.120)$ & $(2.406)$ & $(1.120)$ \\
Pct. Female Faculty & $-.032^{* *}$ & $-.036^{* *}$ & .051 & .052 & $-.031^{*}$ & $-.038^{*}$ & -.050 & -.050 \\
& $(.013)$ & $(.012)$ & $(.043)$ & $(.043)$ & $(.017)$ & $(.016)$ & $(.053)$ & $(.043)$ \\
Pct. Female & - & - & $-.002^{*}$ & $-.002^{*}$ & - & - & $-.002^{*}$ & $-.002^{*}$ \\
Faculty Sq. & & & $(.001)$ & $(.001)$ & & & $(.001)$ & $(.001)$ \\
Pct. Tenure Rank & - & - & - & - & -.001 & .002 & .005 & .008 \\
Female Faculty* & & & & & $(.013)$ & $(.012)$ & $(.013)$ & $(.013)$ \\
Total No. Male & $.059^{* *}$ & $.040^{*}$ & $.056^{* *}$ & $.038^{*}$ & $.060^{* *}$ & $.040^{*}$ & $.054^{*}$ & $.038^{*}$ \\
Faculty & $(.023)$ & $(.019)$ & $(.023)$ & $(.019)$ & $(.023)$ & $(.019)$ & $(.023)$ & $(.019)$ \\
Prestige & -.020 & -.019 & $-.022^{*}$ & $-.021^{*}$ & -.020 & -.019 & $-.022^{*}$ & $-.021^{*}$ \\
& $(.013)$ & $(.012)$ & $(.013)$ & $(.013)$ & $(.013)$ & $(.012)$ & $(.013)$ & $(.013)$ \\
Public Control & $-.627 * *$ & $-.548^{*}$ & $-.622^{* *}$ & $-.550^{*}$ & $-.626^{* *}$ & $-.550^{*}$ & $-.625 * *$ & -.560 \\
& $(.241)$ & $(.235)$ & $(.245)$ & $(.239)$ & $(.241)$ & $(.235)$ & $(.245)$ & $(.239)$ \\
Pct. Ph.D.'s Awarded & -.006 & .001 & -.002 & .005 & -.006 & .002 & -.001 & .006 \\
to Men & $(.016)$ & $(.015)$ & $(.016)$ & $(.015)$ & $(.016)$ & $(.015)$ & $(.016)$ & $(.015)$ \\
Selection Coefficient & -2.961 & - & -2.627 & - & -2.987 & - & -2.501 & - \\
& $(1.954)$ & & $(1.962)$ & & $(1.973)$ & & $(1.989)$ & \\
-2 Log L & 692.81 & 695.13 & 688.58 & 690.39 & 692.80 & 695.11 & 688.42 & 690.02 \\
Model Chi Sq. & $24.66^{* * *}$ & $22.35^{* * *}$ & $28.90^{* * *}$ & $27.09^{* * *}$ & $24.67^{* * *}$ & $22.36^{* * *}$ & $29.05^{* * *}$ & $27.46^{* * *}$
\end{tabular}

'Statistically significant at the .10 level; *at the .05 level; **at the .01 level; ***at the .001 level.

ane year lagged measure.

Source: ASA Guide to Graduate Departments.

The limited explanatory power of the models shown in Table 5 probably reflects the very low rates of turnover at this level. Moreover, the smaller effects for the measures of gender composition in both Tables 4 and 5 relative to those in Table 3 may be partially a function of differences in sampie; 115 cases had no female faculty at the assistant rank, and 170 had no women at tenure rank, compared to only 32 that had no female faculty at either level. Moreover, the striking convergence in the pattern of results shown in the three tables suggests that the demographic composition of a department does exert marked influence on turnover among female faculty.

Although neither of the two theoretical perspectives described above explicitly addresses the issue of the impact of increasing minority group size on majority group outcomes, it may be instructive to examine the effects of gender composition on turnover among male faculty as well. Thus, Tables 6 ,
7 , and 8 present the same set of models, with men's turnover, overall and by rank, as dependent variables.

The effect of increases in the proportion of female faculty on the likelihood of turnover among male faculty at all ranks, as shown in Table 6 , is substantially different from that found in Table 3. In models 1 and 3 , which do not include a quadratic term, the coefficient on the proportion of female faculty is significantly negative, indicating that having more women decreases the likelihood of turnover among male faculty. In models 2 and 4 , the negative coefficient on this variable is nonsignificant, but the quadratic term is both negative and significant.

Table 7, presenting analyses of turnover among assistant rank male faculty, provides the counterpart to Table 4. In this case, none of the demographic variables has any effect on turnover at all. The strongest predictor, far and away, is the absolute 
Table 7. Logistic Regression Coefficients for Models of Turnover Among Male Assistant Professors, 1978-1988.

( $\mathrm{N}=435$; Standard Errors in Parentheses)

\begin{tabular}{|c|c|c|c|c|c|c|c|c|}
\hline Independent Variable & Model 1 & Model 1a & Model 2 & Model $2 a$ & Model 3 & Model 3a & Model 4 & Model $4 a$ \\
\hline Intercept & $\begin{array}{c}-.1 .993 \\
(1.511)\end{array}$ & $\begin{array}{l}-2.300 \\
(1.482)\end{array}$ & $\begin{array}{l}-2.392 \\
(1.617)\end{array}$ & $\begin{array}{l}-2.711^{+} \\
(1.583)\end{array}$ & $\begin{array}{l}-2.062 \\
(1.527)\end{array}$ & $\begin{array}{l}-2.375 \\
(1.495)\end{array}$ & $\begin{array}{l}-2.429 \\
(1.624)\end{array}$ & $\begin{array}{l}-2.749^{*} \\
(1.589)\end{array}$ \\
\hline Pct. Female Faculty" & $\begin{array}{l}.001 \\
(.016)\end{array}$ & $\begin{array}{l}.002 \\
(.016)\end{array}$ & $\begin{array}{l}-.037 \\
(.055)\end{array}$ & $\begin{array}{l}-.040 \\
(.055)\end{array}$ & $\begin{array}{l}.005 \\
(.021)\end{array}$ & $\begin{array}{l}.007 \\
(.021)\end{array}$ & $\begin{array}{l}.039 \\
(.056)\end{array}$ & $\begin{array}{l}.043 \\
(.056)\end{array}$ \\
\hline $\begin{array}{l}\text { Pct. Female } \\
\text { Faculty Sq." }\end{array}$ & - & - & $\begin{array}{l}.001 \\
(.001)\end{array}$ & $\begin{array}{l}.001 \\
(.001)\end{array}$ & - & - & $\begin{array}{l}.001 \\
(.001)\end{array}$ & $\begin{array}{l}-.001 \\
(.001)\end{array}$ \\
\hline $\begin{array}{l}\text { Pct. Tenure Rank } \\
\text { Female Facultya }\end{array}$ & - & - & - & - & $\begin{array}{l}-.005 \\
(.017)\end{array}$ & $\begin{array}{l}-.006 \\
(.017)\end{array}$ & $\begin{array}{l}-.004 \\
(.017)\end{array}$ & $\begin{array}{l}-.005 \\
(.057)\end{array}$ \\
\hline $\begin{array}{l}\text { Total No. Male } \\
\text { Assistants }^{\mathrm{a}}\end{array}$ & $\begin{array}{l}.319^{* * * *} \\
(.059)\end{array}$ & $\begin{array}{l}.303^{* * *} \\
(.056)\end{array}$ & $\begin{array}{l}.319 * * * \\
(.059)\end{array}$ & $\begin{array}{l}.303 * * * \\
(.056)\end{array}$ & $\begin{array}{l}.322 * * * \\
(.060)\end{array}$ & $\begin{array}{l}.307^{* * * *} \\
(.058)\end{array}$ & $\begin{array}{l}.321 * * * \\
(.059)\end{array}$ & $\begin{array}{l}.306 * * * \\
(.057)\end{array}$ \\
\hline Prestige & $\begin{array}{l}.001 \\
(.015)\end{array}$ & $\begin{array}{l}-.005 \\
(.013)\end{array}$ & $\begin{array}{l}-.000 \\
(.015)\end{array}$ & $\begin{array}{l}-.006 \\
(.014)\end{array}$ & $\begin{array}{l}.001 \\
(.015)\end{array}$ & $\begin{array}{l}-.004 \\
(.014)\end{array}$ & $\begin{array}{l}-.000 \\
(.015)\end{array}$ & $\begin{array}{l}-.006 \\
(.014)\end{array}$ \\
\hline Public Control & $\begin{array}{l}-.578 * \\
(.282)\end{array}$ & $\begin{array}{l}-.620 * \\
(.280)\end{array}$ & $\begin{array}{l}-.586^{*} \\
(.283)\end{array}$ & $\begin{array}{l}-.627 * \\
(.279)\end{array}$ & $\begin{array}{l}-.569 * \\
(.285)\end{array}$ & $\begin{array}{l}-.609 * \\
(.281)\end{array}$ & $\begin{array}{l}-.579 * \\
(.284)\end{array}$ & $\begin{array}{l}-.618^{*} \\
(.281)\end{array}$ \\
\hline $\begin{array}{l}\text { Pct. Ph.D.'s Awarded } \\
\text { to Men }\end{array}$ & $\begin{array}{l}.020 \\
(.021)\end{array}$ & $\begin{array}{l}.018 \\
(.021)\end{array}$ & $\begin{array}{l}.022 \\
(.021)\end{array}$ & $\begin{array}{l}.020 \\
(.021)\end{array}$ & $\begin{array}{l}.020 \\
(.021)\end{array}$ & $\begin{array}{l}.018 \\
(.021)\end{array}$ & $\begin{array}{l}.022 \\
(.021)\end{array}$ & $\begin{array}{l}.020 \\
(.021)\end{array}$ \\
\hline Selection Coefficient & $\begin{array}{l}-.966 \\
(.972)\end{array}$ & - & $\begin{array}{l}-.930 \\
(.971)\end{array}$ & - & $\begin{array}{l}-.947 \\
(.974)\end{array}$ & - & $\begin{array}{l}-.918 \\
(.973)\end{array}$ & - \\
\hline$-2 \log L$ & 476.77 & 477.74 & 476.28 & 477.18 & 476.67 & 477.60 & 476.22 & 477.10 \\
\hline Model Chi Sq. & $43.20 * * *$ & $42.23 * * *$ & $43.69^{* * *}$ & $42.79 * * *$ & $43.30^{* * *} 4$ & $42.37^{* * *}$ & $43.75^{* * * *}$ & $42.87 * * *$ \\
\hline
\end{tabular}

+Statistically significant at the .10 level; *at the .05 level; **at the .01 level; ***at the .001 level.

ane year lagged measure.

Source: ASA Guide to Graduate Departments.

number of men at this level. As in other analyses, public control also has a significant, negative effect: private institutions appear to have higher rates of turnover in general.

Table 8 shows the models predicting turnover among tenure rank male faculty. As in Table 6 , the general effect of having an increasing proportion of female faculty is to reduce turnover among male faculty. As in the analyses shown in Table 5 , the coefficient of the sample selection variable is significant and negative. Departments that have lower probabilities of having tenure rank female faculty have a greater likelihood of having turnover among male faculty at tenure levels as well as among female faculty.

There are a number of possible interpretations of the negative relations indicated in Tables 6 and 8 between the proportion of women in the faculty and turnover among men. Although the correlation between percent women and departmental prestige is relatively weak, it is possible that the "feminization" of a department somehow reduces men's chances of mobility. Alternatively, an increase in the proportion of women may enhance male faculty's perceived relative status within the department (see Wharton and Baron 1987) and thus reduce their propensity to move. Whatever the source, the differences in the patterning of results in analyses of turnover among women and men serve to counter the notion that the relationships found between the demographic measures and turnover are likely to be spurious, produced by some general, unobserved departmental characteristics.

\section{Summary and Discussion}

This research extends previous studies of the effects of gender composition on work group relations in a number of ways. 
Table 8. Logistic Regression Coefficients from Models of Turnover Among Tenure Rank Male Faculty, 1978-1988.

$(\mathrm{N}=380$; Standard Errors in Parentheses)

\begin{tabular}{lcccccccc}
\hline Independent Variable & Model 1 & Model 1a & Model 2 & Model 2a & Model 3 & Model 3a & Model 4 & Model 4a \\
\hline Intercept & $6.017^{* *}$ & $3.841^{* *}$ & $5.568^{* *}$ & $3.411^{*}$ & $6.084^{* * *}$ & $3.795^{* *}$ & $5.434^{* *}$ & $3.173^{*}$ \\
& $(1.891)$ & $(1.435)$ & $(1.982)$ & $(1.570)$ & $(1.896)$ & $(1.439)$ & $(1.991)$ & $(1.611)$ \\
Pct. Female Faculty & $-.072^{* * *}$ & $-.076^{* * *}$ & -.023 & -.032 & $-.082^{* * *}$ & $-.081^{* * *}$ & -.013 & -.027 \\
& $(.018)$ & $(.018$ & $(.067)$ & $(.067)$ & $(.022)$ & $(.023)$ & $(.068)$ & $(.067)$ \\
Pct. Female & - & - & -.001 & -.001 & - & - & -.002 & -.001 \\
Faculty Sq. & & & $(.002)$ & $(.002)$ & & & $(.002)$ & $(.002)$ \\
Pct. Tenure Rank & - & - & - & - & .015 & .008 & .024 & .015 \\
Female Faculty* & & & & & $(.021)$ & $(.021)$ & $(.023)$ & $(.023)$ \\
Total No. Tenure & $.062^{*}$ & .026 & $.064^{*}$ & .027 & $.068^{*}$ & .028 & $.075^{*}$ & .031 \\
Rank Male Faculty & $(.033)$ & $(.026)$ & $(.033)$ & $(.026)$ & $(.034)$ & $(.026)$ & $(.034)$ & $(.026)$ \\
Prestige & -.019 & -.018 & -.020 & -.019 & -.019 & -.018 & -.021 & -.019 \\
& $(.018)$ & $(.017)$ & $(.018)$ & $(.018)$ & $(.018)$ & $(.018)$ & $(.018)$ & $(.018)$ \\
Public Control & $-.614^{*}$ & $-.636 *$ & $-.615 *$ & $-.638^{*}$ & $-.625^{*}$ & $-.642^{*}$ & $-.633^{*}$ & $-.650^{*}$ \\
& $(.287)$ & $(.284)$ & $(.289)$ & $(.286)$ & $(.287)$ & $(.284)$ & $(.289)$ & $(.286)$ \\
Pct. Ph.D.'s Awarded & $-.058^{* *}$ & $-.037 *$ & $-.057 * *$ & $-.036 *$ & $-.059^{* *}$ & $-.037 *$ & $-.059 * *$ & $.035^{*}$ \\
to Men & $(.022)$ & $(.019)$ & $(.022)$ & $(.019)$ & $(.022)$ & $(.019)$ & $(.022)$ & $(.019)$ \\
Selection Coefficient & $-.1 .952^{*}$ & - & $-.1 .979^{*}$ & - & $-2.084^{*}$ & - & $-2.210^{*}$ & - \\
& $(1.068)$ & & $(1.066)$ & & $(1.086)$ & & $(1.091)$ & \\
-2 Log L & 450.33 & 453.70 & 449.70 & 453.22 & 449.83 & 453.55 & 448.63 & 452.78 \\
Model Chi Sq. & $36.59 * * *$ & $33.20^{* * *}$ & $37.18^{* * *}$ & $33.70^{* * *}$ & $37.09^{* * *}$ & $33.37 * * *$ & $38.29 * * *$ & 34.14 \\
\hline
\end{tabular}

'Statistically significant at the .10 level; *at the .05 level; **at the .01 level; ***at the .001 level. ane year lagged measure.

Source: ASA Guide to Graduate Departments.

As noted at the outset of the paper, most existing work on gender composition has concentrated on attitudinal outcomes of variations in composition; few studies have examined behavioral outcomes directly.

Although social contact and competition theories are predicated on arguments about the impact of changing group proportions on attitudes, both perspectives were developed with the aim of explaining behavioral outcomes as well (Blalock 1967; Simpson and Yinger 1972). Thus, by examining the impact of gender composition on turnover probabilities as an aspect of group behavior, this research offers a strong test of these theories. In addition, the design of this study, based on data collected from a relatively large number of organizations over an extended period of time, permits a more systematic assessment of the relationship between group proportions and outcomes than previous studies, which have typically relied on cross-sectional data or data drawn from a single organization (Talbert and Bose 1978; Fox 1985; Tolbert 1986; Tolbert and Oberfield 1991). Finally, our study contributes to the literature on determinants of turnover as well, extending the contemporary line of analyses linking demographic composition to turnover to include gender composition as a relevant demographic attribute of groups.

The empirical findings from analyses of turnover among women are generally consistent with arguments derived from competition theory, namely, that women's growing representation in work groups leads to an increasingly negative environment for them, thus increasing the likelihood of their leaving the group. These results are directly contrary to those predicted by social contact theory. It may be that the straitened conditions facing many sociology departments during the period studied here, resulting from declining student enrollments and general fiscal pressures on 
universities, provided a context in which competitive rather than integrative dynamics were more likely to be generated by changes in group proportions; under other conditions, perhaps, social contact theory would fare better. However, it is worth noting that despite its intuitive appeal (and thus, perhaps, its continuing existence as a theoretical framework), intensive research based on social contact theory has identified a succession of limiting scope conditions, and generally suggests that while social contact may have some impact on attitudes under specified conditions, it tends to produce minimal effects on behavior (see Cook 1971; Hewstone and Brown 1986).

Interestingly, the general finding from our analyses of turnover among male faculty-namely, that increases in the proportion of women in a department had little impact or even a negative impact on men's turnover-differs sharply from the results of our analyses of turnover among women. We have suggested several possible explanations for the negative effects, but the most important, general implication of the differences between the results of our analyses of men and women is that changes in group proportions may affect members of minority and majority groups quite differently. Future research on group demographic composition should address this issue, since a full understanding of the impact of group demography necessarily rests on knowledge of effects on "in-group" as well as "out-group" members.

Finally, the findings of this research raise some issues about the effective implementation of affirmative action policy in higher education. Insofar as affirmative action efforts produce a relatively unsupportive social environment for female and minority faculty, as suggested here (see also Heilman 1994), the effectiveness of women and minorities as role models and signals of opportunity may be limited. A key policy implication of this study is that, in order to effectively fulfill broad, long-run objectives of reducing occupational segregation by race and sex, more attention must be given to understanding and mediating group dynamics that may accompany demographic change brought about by affirmative action. 


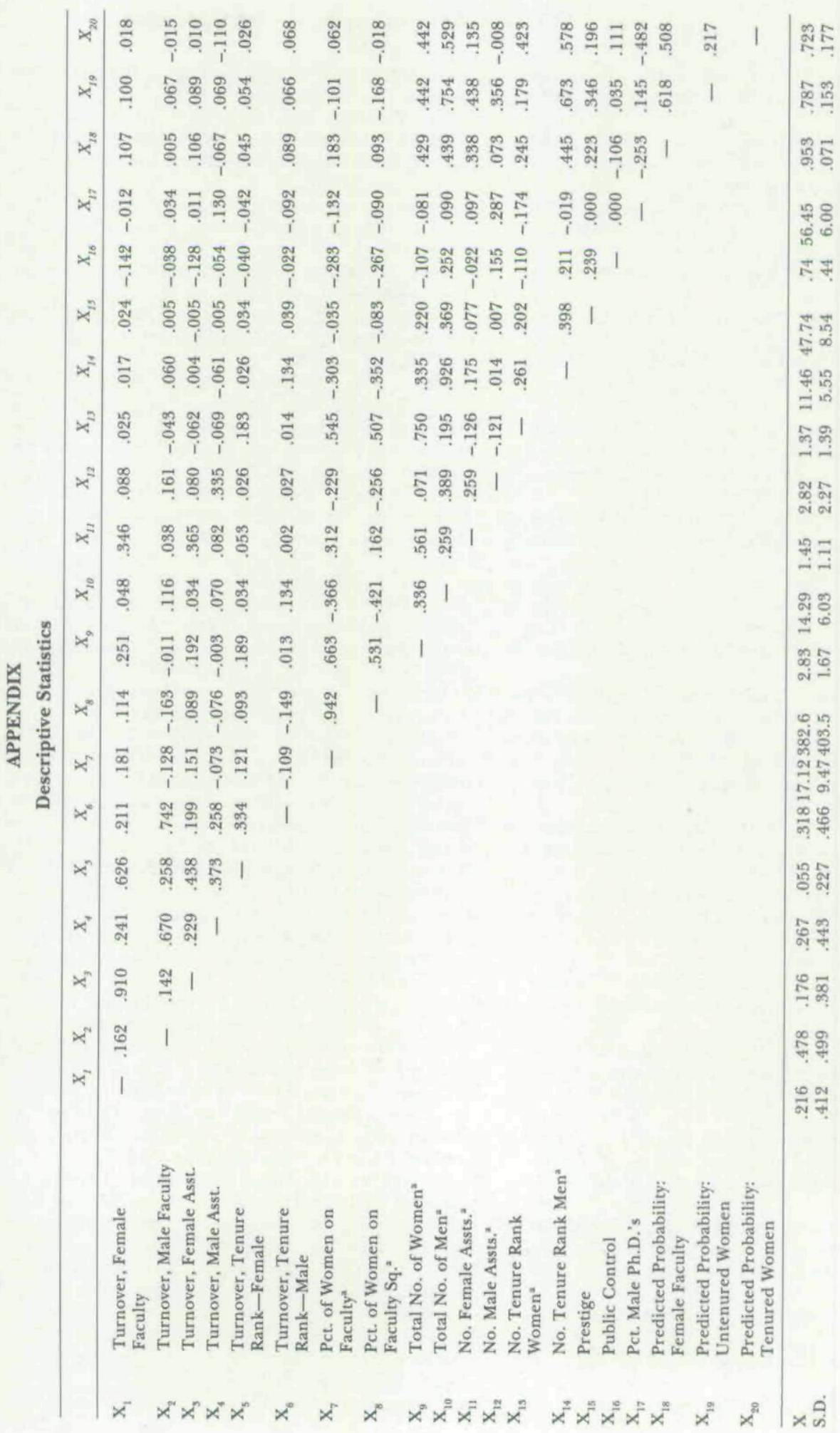




\section{REFERENCES}

Allison, Paul. 1984. Event History Analysis: Regression for Longitudinal Event Data. Beverly Hills, Calif.: Sage.

Allison, Paul, and Scott Long. 1990. "Departmental Effects on Scientific Productivity." American Sociological Review, Vol. 55, pp. 469-78.

Allmendinger, Jutta, and Richard Hackman. 1993. "The More, the Better? On the Inclusion of Women in Professional Organizations." Harvard University Business School, Division of Research, Working Paper No. 94-005.

Allport, Gordon. 1954. The Nature of Prejudice. Cambridge, Mass.: Addison Wesley.

Andersen, C. J., D. J. Carter, and A. G. Malizio. 1991. 1989-90 Fact Book on Higher Education. New York: MacMillan.

Beck, E. M., and Stewart Tolnay. 1990. "The Killing Fields of the Deep South: The Market for Cotton and the Lynching of Blacks, 1882-1930." American Sociological Review, Vol. 55, pp. 526-39.

Berk, Richard. 1983. "An Introduction to Sample Selection Bias in Sociological Data." American Sociological Review, Vol. 48, pp. 386-98.

Blalock, Hubert. 1957. "Percent Non-White and Discrimination in the South." American Sociological Review, Vol. 22, pp. 677-682.

1967. Toward a Theory of Minority Group Relations. New York: Wiley.

Blank, Rebecca. 1991. "The Effects of Double-Blind Versus Single-Blind Reviewing: Experimental Evidence from the American Economic Review." American Economic Review, Vol. 81, pp. 1041-67.

Blau, Peter. 1977. Inequality and Heterogeneity. New York: Free Press.

Bonacich, Edna. 1972. "A Theory of Ethnic Antagonism: The Split Labor Market." American Sociological Review, Vol. 38, pp. 547-59.

Broder, Ivy. 1993. "Review of NSF Economic Proposals: Gender and Institutional Patterns." American Economic Review, Vol. 83, pp. 964-70.

Brown, David, and Glenn Fuguitt. 1972. "Percent Nonwhite and Racial Disparity in Non Metropolitan Cities in the South." Social Science Quarterly, Vol. 53, pp. 573-82.

Cook, S. W. 1971. "Interpersonal and Attitudinal Outcomes in Cooperating Interracial Groups." Journal of Research and Development in Education, Vol. 12, pp. 97-113.

1979. "Social Science and School Desegregation: Did We Mislead the Supreme Court?" Personality and Social Psychology Bulletin, Vol. 5, pp. 42004437.

Crane, Diana. 1965. "Scientists at Major and Minor Universities: A Study of Productivity and Recognition." American Sociological Review, Vol. 30, pp. 669713.

Edelman, Lauren. 1992. "Legal Ambiguity and Symbolic Structures: Organizational Mediation of Civil Rights Law." American Journal of Sociology, Vol. 97, pp. 117-40.

Fox, Mary Frank. 1985. "Sex Segregation and Salary
Structure in Academia." Sociology of Work and Occupations, Vol. 8, pp. 39-60.

Frisbie, W. Parker, and Lisa Neidert. 1977. "Inequality and the Relative Size of Minority Populations: A Comparative Analysis." American Journal of Sociology, Vol. 82, pp. 1007-30.

Heckman, James. 1979. "Sample Selection Bias as a Specification Error." Econometrica, Vol. 47, pp. 15361.

Heilman, Madeline. 1994. "Affirmative Action: Some Unintended Consequences for Working Women." In B. Staw and L. Cummings, eds., Research in Organizational Behavior. Greenwich, Conn.: JAI Press, Vol. 16, pp. 125-69.

Hewstone, Miles, and Rupert Brown. 1986. "Contact Is Not Enough: An Intergroup Perspective on the 'Contact Hypothesis.' Brown, eds., Contact and Conflict in Intergroup Encounters. London: Blackwell, pp. 1-44.

Izraeli, Daphna. 1983. "Sex Effects or Structural Effects? An Empirical Test of Kanter's Theory of Proportions." Social Forces, Vol. 62, pp. 153-65.

Jackson, S. E., J. F. Brett, V. I. Sessa, D. M. Cooper, J. A. Julin, and K. Peyronnin. 1991. "Some Differences Make a Difference: Individual Dissimilarity and Group Heterogeneity as Correlates of Recruitment, Promotions, and Turnover." Journal of Applied Psychology, Vol. 76, pp. 675-89.

Kanter, Rosabeth M. 1977. Men and Women of the Corporation. New York: Basic Books.

Long, Scott. 1992. "The Origins of Sex Differences in Science." Social Forces, Vol. 70, pp. 159-78.

Long, Scott, Paul Allison, and Robert McGinnis. 1993. "Rank Advancement in Academic Careers: Sex Differences and the Effects of Productivity." American Sociological Review, Vol. 58, pp. 703-22.

National Center for Education Statistics. 1993. Digest of Educational Statistics. Washington, D.C.: GPO.

Mowday, Richard, Lyman Port, and Richard Steers. 1982. Employee-Organization Linkages: The Psychology of Commitment Absenteeism and Turnover. New York: Academic Press.

O'Reilly, Charles, Debra Caldwell, and William Barnett. 1989. "Work Group Demography, Social Integration, and Turnover." Administrative Science Quarterly, Vol. 34, pp. 21-37.

Pettigrew, Thomas. 1986. "The Intergroup Contact Hypothesis Reconsidered." In M. Hewstone and R. Brown, eds., Contact and Conflict in Intergroup Encounters. London: Blackwell, pp. 353-90.

Pfeffer, Jeffrey, and Alison Davis-Blake. 1987. "The Effect of the Proportion of Women on Salaries: The Case of College Administrators." Administrative Science Quarterly, Vol. 33, pp. 588-606.

Reed, John. 1972. "Percent Black and Lynching: A Test of Blalock's Theory." Social Forces, Vol. 50, pp. 356-65.

Rosenfeld, Rachel, and Jo Ann Jones. 1986. "Institutional Mobility Among Academics." Sociology of Education, Vol. 59, pp. 212-26.

Schneider, Benjamin. 1983. "An Interactionist Per- 
spective on Organizational Effectiveness." In L. Cummings and B. Staw, eds., Research in Organizational Behavior. Greenwich, Conn.: JAI Press, Vol. 5, pp. 1-31.

Segal, Bernard. 1962. "Male Nurses: A Case Study in Status Contradiction and Prestige Loss." SocialForces, Vol. 41, pp. 31-38.

Simpson, George, and J. M. Yinger. 1972. Racial and Cultural Minorities: An Analysis of Prejudice and Discrimination. New York: Harper \& Row.

South, S. J., C. M. Bonjean, W. T. Markham, and J. Corder. 1982. "Social Structure and Intergroup Interaction: Men and Women of the Federal Bureaucracy." American Sociological Review, Vol. 47, pp. 587-99.

1987. "Sex Differences in Support for Organizational Advancement." Work and Occupations, Vol. 14, pp. 261-85.

Sowell, Thomas. 1976. "Affirmative Action Reconsidered: Was It Necessary in Academia?" In U.S. Commission on Civil Rights, eds., Affirmative Action in Employment in Higher Education. Washington, D.C.: GPO, pp. 23-49.

Spangler, Eve, Marsha Gordon, and Ronald Pipkin. 1978. "Token Women: An Empirical Test of Kanter's Hypothesis." American Journal of Sociology, Vol. 84, pp. $160-70$,

Talbert, Joan, and Christine Bose. 1977. "WageAttainment Processes: The Retail Clerk Case." American Journal of Sociology, Vol. 83, pp. 403-24.

Task Force on Women, Minorities, and the Handi- capped in Science and Technology. 1989. Changing America: The New Face of Science and Engineering. Washington, D.C.: GPO.

Tolbert, Pamela. 1986. "Organizations and Inequality: Sources of Earnings Differences Between Male and Female Faculty." Sociology of Education, Vol. 59, pp. 227-36.

Tolbert, Pamela, and Alice Oberfield. 1991. "Sources of Organizational Demography: Faculty Sex Ratios in Colleges and Universities." Sociology of Education, Vol. 64, pp. 305-16.

Toren, Nina, and Vered Kraus. 1987. "The Effects of Minority Size on Women's Position in Academia." Social Forces, Vol. 65, pp. 1090-1100.

Tsui, Anne, Terri Egan, and Charles O'Reilly, 1992. "Being Different: Relational Demography and Organizational Attachment." Administrative Science Quarterly, Vol. 37, pp. 554-79.

Wagner, Gary, Jeffrey Pfeffer, and Charles O'Reilly. 1984. "Organizational Demography and Turnover in Top-Management Groups." Administrative Science Quarterly, Vol. 29, pp. 74-92.

Wharton, Amy, and James Baron. 1987. "So Happy Together? The Impact of Gender Segregation on Men at Work." American Sociological Review, Vol. 52, pp. 574-87.

Wolman, Carol, and Hal Frank. 1975. "The Solo Woman in a Professional Peer Group." American Journal of Orthopsychiatry, Vol. 45, pp. 164-71.

Yamaguchi, Kazuo. 1991. Event History Analysis. Newbury Park, Calif.: Sage. 